\title{
Assessment of the Profitability of Environmental Activities in Forestry
}

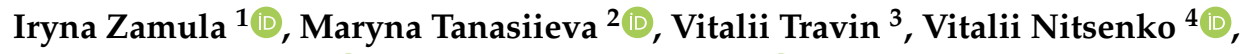 \\ Tomas Balezentis ${ }^{5, *(D)}$ and Dalia Streimikiene ${ }^{5}$ (D) \\ 1 Department of Accounting and Audit, Zhytomyr Polytechnic State University, 10004 Zhytomyr, Ukraine; \\ zamula@ztu.edu.ua \\ 2 Department of Accounting, Analysis and Audit, Yuriy Fedkovych Chernivtsi National University, \\ 58012 Chernivtsi, Ukraine; m.tanasiyeva@chnu.edu.ua \\ 3 Department of Digital Economics and International Economic Relations, Zhytomyr Polytechnic State \\ University, 10004 Zhytomyr, Ukraine; travin@ztu.edu.ua \\ 4 Department of Accounting and Taxation, Interregional Academy of Personnel Management, \\ 03039 Kyiv, Ukraine; vitaliinitsenko@onu.edu.ua \\ 5 Division of Farm and Enterprise Economics, Lithuanian Institute of Agrarian Economics, \\ 03220 Vilnius, Lithuania; dalia@mail.lei.lt \\ * Correspondence: tomas@laei.lt
}

Received: 14 February 2020; Accepted: 4 April 2020; Published: 8 April 2020

check for updates

\begin{abstract}
The paper presents a framework for the financial analysis of the environmental measures (programmes) for forestry enterprises. The indicators of the economic and social effectiveness of environmental measures are discussed. The prospects for their implementation in the context of sustainable forest management in Ukraine are analysed. The research focuses on the effectiveness of environmental measures at the level of forestry enterprise. The proposed framework allows for determining the economic and social effectiveness of environmental measures at the enterprise level. To this end, the net discounted income is used to measure the profitability of environmental measures. The payback period is determined to provide an intuition behind the decision to participate in the environmental measures. The proposed framework allows for improving decision support for the national sustainable forestry development programmes not only at the macro level, but also at the level of enterprises.
\end{abstract}

Keywords: environmental activities; management decisions; mathematical model; environmental performance assessment; net discounted income; forestry

\section{Introduction}

Today, forest resources are of paramount importance for all those living on the planet, and, in particular, for ensuring human life. In the economy of the state, the forest industry plays a special role, since it is both a strategic resource of the economy and a factor of stability. The Food and Agriculture Organization of the UN (FAO) [1] emphasizes that forests play a fundamental role in ensuring food security and improving the living conditions of people, ensuring the most effective use of the full range of economic, social and environmental benefits associated with the integration of forests into agriculture and recreation. Forests and agriculture have a significant role to play in meeting the historic challenge, which is stated in the document "Transforming our World: The 2030 Agenda for Sustainable Development" to rid the world of two scourges-poverty and hunger.

A significant role in the sustainable development of forestry is played by the Forest Stewardship Council and the Sustainable Green Ecosystem Council through the proposed scheme of the international forest certification. Cooperation with such organizations should be increased to ensure reliable 
monitoring of forest use in countries around the world [2,3]. It is clear that the proposed certification scheme requires the usage of appropriate methodological accounting tools.

Despite the improvements evidenced by the main statistical indicators of the state of forests in Ukraine [4], there is a number of significant problems in forest management. Some of them are the unsustainable use of forest resources, illegal logging, industrial air pollution, excessive use of chemical means of protecting forests from diseases and pests of forest vegetation and also forest wildfires.

The solution to these problems requires the board of the national system of eco-oriented forest management by the industry, taking into account the Sustainable Development Goals for 2016-2030. The sustainability issues are important not only at the macro level, but also at the level of forest subjects. The goals of sustainable development in the forestry of Ukraine provide environmental and economic aspects of sustainable development. The environmental aspect of sustainable forestry development implies the preservation of the environment, the biological diversity of forest ecosystems, the rational use of natural resources, the protection of the atmosphere, land, subsoil, forests, water, and the ecologically safe use of biotechnology (Goals 6, 12, 13, 15). The economic aspect reflects the balance of economic interests of the main subjects of forest relations: the state, the owner of the forests, forest users, the management authorities of forests at all levels and the public (Goals 2, 3, 7, 8, 12) [5]. To show the importance of the analysis of the effectiveness of the implementation of environmental measures in forestry, Table 1 depicts the dynamics of the main financial and economic indicators of forestry enterprises in Ukraine for 2015-2018.

Table 1. Main financial and economic indicators of activity of forestry enterprises of Ukraine for 2015-2018 [5,6].

\begin{tabular}{|c|c|c|c|c|c|}
\hline Indicator, Dimension & 2015 & 2016 & 2017 & 2018 & Rate of Growth, \% \\
\hline Forest area, thousand ha & $10,630.3$ & $10,423.1$ & $10,674.9$ & $10,674.9$ & 0.4 \\
\hline out of which covered with tree cover & 9695.2 & 9690 & 8424.6 & 8424.6 & -5.6 \\
\hline Cutting area, thousand ha & 399.3 & 386.3 & 419.1 & 445.5 & 4.1 \\
\hline $\begin{array}{c}\text { Volume of harvested liquid wood, } \\
\text { thousand } \mathrm{m}^{3}\end{array}$ & $21,924.2$ & $22,602.3$ & 21,923 & $22,529.7$ & 0.5 \\
\hline Area of forest reproduction, thousand ha & 60.4 & 63.2 & 64.7 & 51.5 & -4.5 \\
\hline Cost of sold forest products, thousand EUR & $296,613.3$ & $306,352.1$ & 340,421 & $390,021.8$ & 9.3 \\
\hline Operating expenses, thousand EUR & $36,751.16$ & $23,622.66$ & $25,728.49$ & $30,803.71$ & -4.4 \\
\hline Net profit, thousand EUR & $41,326.67$ & $26,119.21$ & $16,757.6$ & $14,526.34$ & -35.8 \\
\hline
\end{tabular}

Note: stochastic annual rates of growth based on the lin-log regression are given.

According to Table 1, one can observe that the increasing cutting and slightly increasing volume of the harvested wood led to a decline in the net profit of the Ukrainian forestry enterprises during 2015-2018. The area covered with the tree crown cover and the area of forest reproduction also declined. This indicates the need for analysis of the profitability and environmental performance of the Ukrainian forestry sector.

Many types of environmental problems arise which require diverse indicators and protocols for their analysis. The environmental performance indicators (EPIs) can assist the analysts in these instances. The EPIs relate the economic activities to the environmental pressures. Indeed, these environmental pressures may often remain external to the companies and would not be accounted for in such traditional performance measures as, e.g., financial indicators. The environmental measures (and the associated EPIs) can be measured in a number of ways [7-9]. In particular, EPIs are designed to describe such issues as pollution, biodiversity, climate, energy use, erosion, ecosystem services, and environmental education, among others $[10,11]$. The EPIs are often combined with other indicators by establishing indicator systems for sustainability assessment $[12,13]$.

One of the main factors influencing the efficiency of enterprise management is the provision of an effective accounting and analytical system, which, with the help of relevant information, will allow controlling the volume and condition of forest resources, to characterize the efficiency of environmental activities of forestry for the purpose of making management decisions. 
The purpose of this study is to define the peculiarities of environmental performance analysis of forestry enterprises in accordance with the requirements of the Sustainable Development Goals for 2016-2030. In order to build the methodology of such analysis which will contribute to the effectiveness of measures for the protection and reproduction of the country's forest resources, the following tasks were undertaken: developing the methodology for environmental analysis by establishing a system of indicators to assess the economic, environmental and social effectiveness of environmental measures; constructing an economic-mathematical model of efficiency analysis of environmental performance of forestry enterprises (public and private forms of property). The research is based on the official data from the State Forest Resources Agency of Ukraine, State Statistics Service of Ukraine, the actual information of the forestry enterprises of Ukraine and the results of the questionnaire of the heads of such enterprises.

\section{The Status of Implementation of Environmental Measures for Forestry in Ukraine}

On the basis of processing and generalization of theoretical studies and taking into account the practical experience of forestry enterprises, environmental measures are systematized depending on the content, purpose and objects of environmental activity [14,15]. The main environmental activities of forestry are: the construction and maintenance of waste disposal facilities for timber and woodworking industry; the prevention, timely detection and control of forest fires; the prevention and management of windbreaks, snow breaks and other natural disasters; the prevention and elimination of negative effects of technogenic effects on forest plantations; the protection of forests from unauthorized logging, damage and other forest violations; monitoring forest users' compliance with forest leave regulations; and control of harmful insects and forest diseases; conservation and reproduction costs; the construction and maintenance of permanent forest roads, providing access to all areas of the forest; and the establishment of plants and laboratories for the biological and chemical protection of forest plantations.

The technological specificity of the environmental activities of forest farms is due to the following characteristic features of forest management: the direct relationship between environmental activities and their dependence on the main technological process, which makes it difficult to allocate environmental costs in their entirety; versatility of environmental measures related to forest management in accordance with types of logging technology, reforestation, wood processing; technology dependence for environmental management from the use of forest resources.

Considering that Ukraine has not yet approved the project Forests of Ukraine-2030, whose main purpose is to intensify its work on forest reproduction and protection, the only relevant source of size and composition of nature conservation measures in forestry is the report on the results of the implementation of the state target programme "Forests of Ukraine" for 2010-2015. The results of the implementation of environmental measures in accordance with the tasks of the state target programme "Forests of Ukraine" for 2010-2015 testify the positive dynamics of their volumes and confirm the achievements of the planned results (Figure 1). 


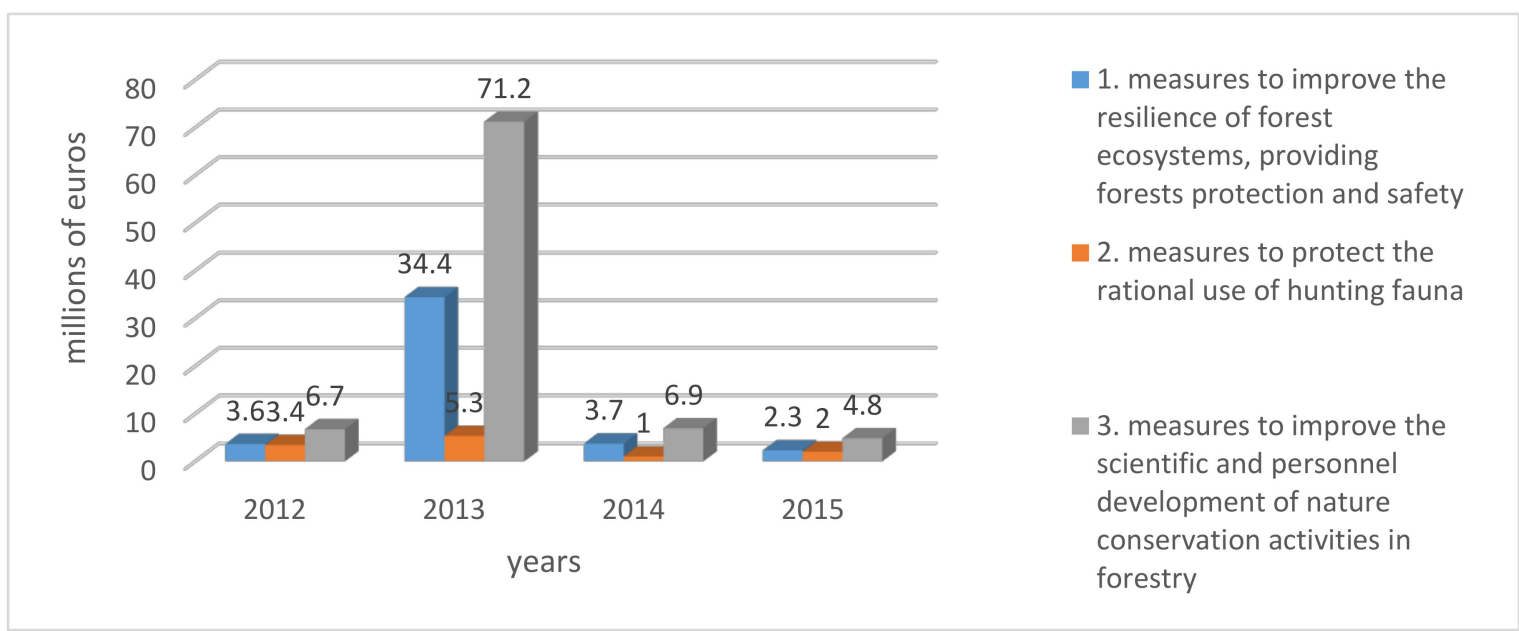

Figure 1. Dynamics of environmental measures in accordance with the tasks of the state target programme "Forests of Ukraine" for 2012-2015. Source: development of authors using the results of state target programme "Forests of Ukraine" for 2012-2015 [16].

The expenses for environmental protection are rising annually and are carried out at the both the state budget and own sources of funds of forestry enterprises. Analysis of costs for environmental protection in forestry and logging testify to positive dynamics of their sizes and confirm the relevance of the study of such costs, particularly within the private forestry enterprises (Figure 2).

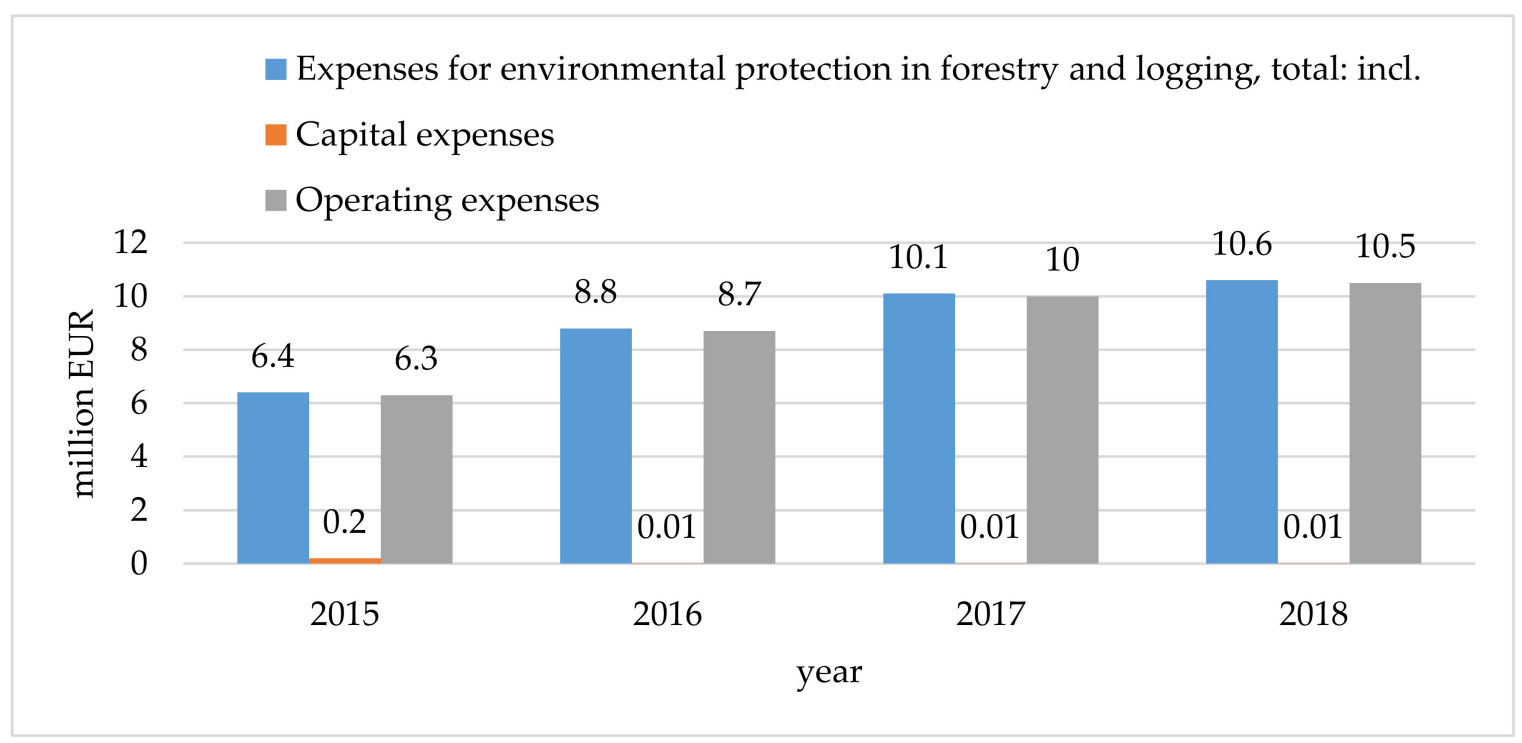

Figure 2. Analysis of costs for environmental protection in forestry and logging for 2015-2018. Source: development of authors using the results of Environment of Ukraine 2018, 2019 [4].

The sources of expenses for environmental protection in forestry and logging were rather stable during 2015-2018 (Figure 3). As the State Statistics Service of Ukraine provides data about expenditures by the state budget from the General Fund and special funds and private sources (i.e., funds of the forestry enterprises), one can identify the major contributors to the environmental measures in the forestry sector of Ukraine. Obviously, more than $90 \%$ of the funding comes from the forestry enterprises themselves [4]. Therefore, there is a need to identify the effectiveness of these measures. 


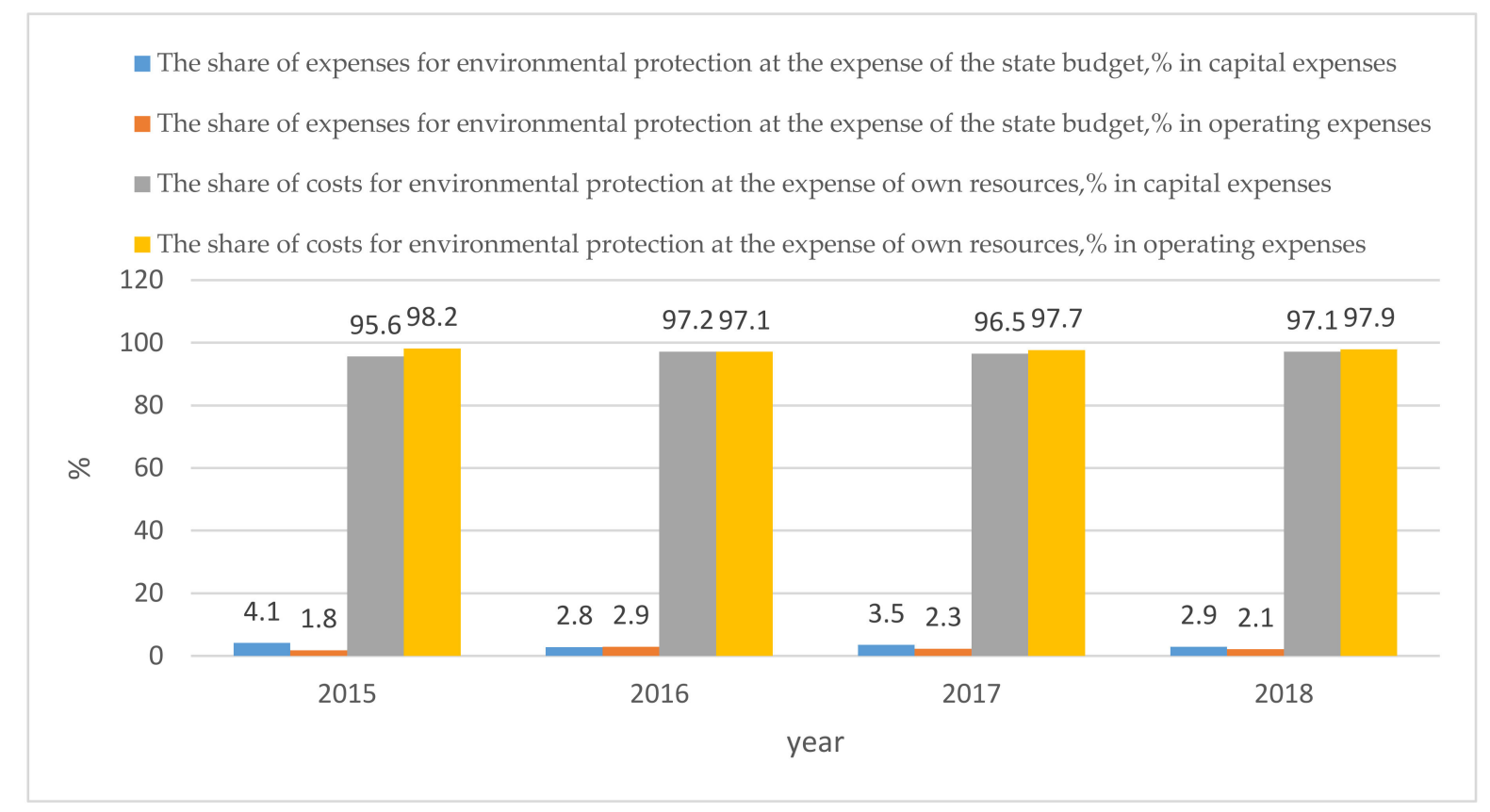

Figure 3. Expenditure on environmental protection in forestry from financing sources for 2015-2018. Source: developed by the authors using the results of Environment of Ukraine 2018, 2019 [4].

\section{Literature Review}

The integration of environmental considerations into economic analysis rewards attention [17-19]. Indeed, issues related to the environment in the economic, social and ecological performance of the forestry sector which are important in the context of sustainability [9].

The environmental accounting of enterprises is becoming more and more important. The growing complexity of business in the face of the exhaustion of natural resources leads to relevant information requests. It is important to adapt to the changing environment in a timely manner, applying creativity and forecasting for modern efficient management. Therefore, in European countries, environmental accounting is a complex system which combines the features of the main functions of management; that is, organization, planning, analysis and control [20]. Equally important is the empirical assessment and study of factors that influence environmental management accounting and economic performance [21], particularly with regard to assessment and reporting prepared by enterprises, taking into account the integration of performance appraisal indicators into the overall management system [22].

The use of an appropriate environmental management accounting system helps to improve the environmental performance of business entities [23]. The role of accounting management systems in influencing environmental uncertainty and energy efficiency on economic and environmental performance of enterprises is becoming increasingly important in scientific research [24].

The solution of individual theoretical and methodological problems is devoted to fundamental scientific research $[25,26]$. However, development issues in the accounting of environmental activities remain relevant, in particular the possibilities of information provision for assessing the effectiveness of environmental activities. Current publications have covered the role of environmental accounting and general principles of the organization at the enterprise [27]. Krivačić, and Janković also demonstrated the importance of establishing due environmental reporting for the management needs [28]. The impact of harmonising the environmental accounting information system on the environmental performance of small and medium-sized enterprises was also analysed [29]. In addition, there has been research on the relationship between environmental accounting and management in the context of both environmental and economic performance of enterprises [30]. Cavatassi proved the influence of proper planning, accounting and control of environmental activities on the formation of financial results of the enterprise [31]. 
In the framework of the growing role, the issues of the effectiveness of the use of forest resources become an exhaustive natural resource, in which the development of measures for its conservation is required. In order to provide adequate information support for optimal management decisions, environmental accounting has to be integrated into the economic structure of the enterprise and to take maximum account of the sectoral features of forest management [32].

Current research is on trends in the development of the accounting of environmental activities in the European forest industry [33]. In particular, Toscani and Sekot claimed that the Forest Accountancy Data Network is a modern European information source of research in forest economics at the enterprise level [34]. The proposed method involves the multiple use of the forest resources according to the aspects of sustainable development.

The effective forestry activities are widely investigated in the eastern countries. Scientists are exploring the role of accounting and environmental management systems in assessing the impact of environmental strategy tools, uncertainty, and management commitments on China's environmental performance [35]. The frontier methods can also be applied for measuring environmental performance, e.g., analysis of state forestry enterprises in Northeast China [36].

Life cycle analysis has become an important concept in the environmental performance of forest enterprises [37]. Carbon budgeting can be established for the life cycle of the forest products. These indicators can supplement the economic dimension of the analysis. However, life cycle analysis is data-intensive and requires detailed descriptions of the operations involved in the production of each specific product.

The analysis of the efficiency of ecologically balanced systems of forest management in Ukraine, on the basis of which a modern system of social and economic measures to improve the functioning of the industry, was proposed [38,39]. However, the holistic accounting and analytical support system for environmental management is absent in forestry. Taking into account the economic, ecological and social aspects is still needed in the accounting practice of Ukrainian forest management. The activities of forestry enterprises have many branches. Therefore, for proper accounting and analytical support of environmental management $n$ such enterprises it is necessary to have detailed research and to take into account the influence of such features, while developing systematic methodologies and assessment of the effectiveness of forest enterprises' environmental measures, which will take into account the economic, environmental and social aspects of the forest resources use.

\section{Results}

\subsection{Accounting of Environmental Activities in Forestry}

As part of the usual activities of economic entities, operational, financial and investment activities are distinguished. Economic activity for the majority of enterprises, including forest farms, should be based on the maximization of the effectiveness of operational activity that is a significant and fundamentally important activity of the enterprise, and corresponds to the main purpose of its creation and functioning. The main features of the operational activity, which distinguishes it from other activities, are the constant repeatability and regularity of economic operations. The operational activities of forest enterprises include such processes as afforestation, reforestation, logging, woodworking and implementation. The above processes form an industry affiliation, and therefore have a direct influence on the construction of the accounting system.

The organizational characteristics of the forestry enterprises are related to the presence of different types and purposes of production processes [40]. However, the accounting system is most influenced by the technological features of the main forestry activity; in particular, the completeness of the technological process (the presence of advanced logging and woodworking production), and high labor capacity (logging) and material capacity (wood processing) availability of primary related products and waste (Figure 4). A significant amount of accounting information is about tools and work items. 


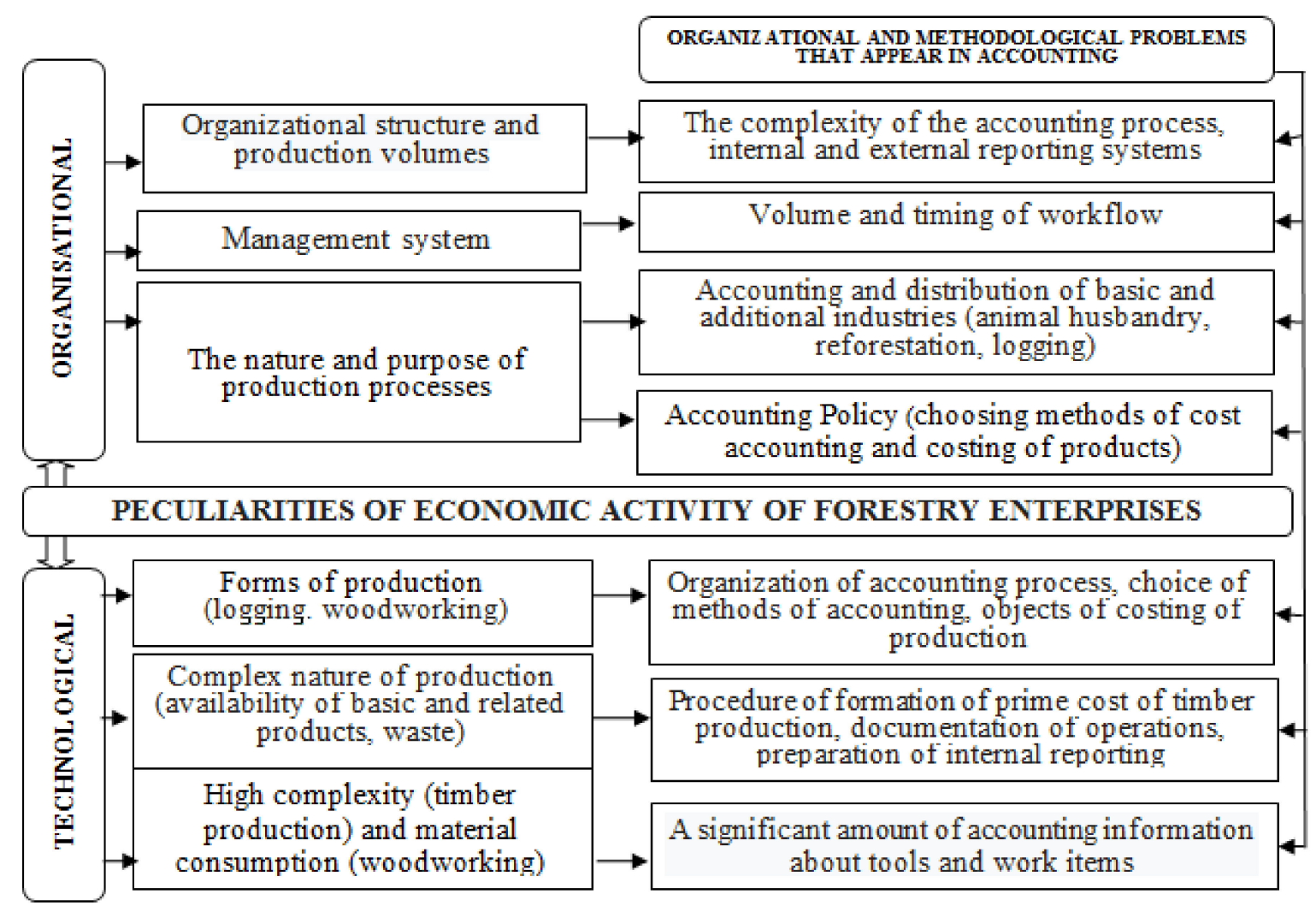

Figure 4. Influence of forestry industry features on accounting system. Source: development of authors using the results of $[18,41]$.

Thus, the process of using forest resources is connected with their depletion, as a result of which the enterprises of forest hectares of meadows actively participate in their protection and reproduction. This confirms the direct relationship between forest management and environmental protection. We propose to consider the activities aimed at achieving the maximum socio-economic effect of improving the state of forests, their management, integrated processing and conservation of forest resources.

Based on the identified aspects of environmental activities in forestry, their impact on the accounting and analysis system is determined, namely, the need to improve the analytical nature of accounting information on environmental activities through its diversity, and the need to organize the collection, processing and timely submission of information to users in a rational manner.

The study identified a number of factors that negatively affect the implementation of environmental activities, in particular, non-compliance with logging technology and the increase in purchasing prices for raw materials, fuel and lubricants and energy resources [42]. These factors have a significant impact on environmental performance. In order to eliminate them quickly, it is necessary to have complete information on the costs of environmental activities, formed mainly in the accounting system and ensuring the timeliness of its receipt $[18,43]$. It is obvious that it is impossible to evaluate environmental performance without information from the accounting system and the introduction of organizational and methodological provisions for environmental analysis. This will provide information and needs and users at all levels of management.

Most of the input information necessary for environmental performance analysis is formed in the accounting system. Reviews of the current environmental accounting techniques were proposed in the scientific literature. They were based on the use of a separate synthetic account (subaccount) and/or the use of special accounting articles for production cost accounting. The use of a combined method of accounting for current environmental costs has been proved, which provides the use of sub-account 237 "Environmental costs", which is of a costing nature. Analytical accounting is proposed to be 
carried out by structural units, within the framework of specific environmental activities, with division by place of occurrence of costs and objects of expenditure. In the case of the complexity of attributing environmental costs to the cost of specific products, it is proposed to use sub-account 915 "Expenditure on environmental protection" in accordance with the developed nomenclature of costs.

In order to streamline the accounting of environmental costs, taking into account the nature protection characteristics of forestry enterprises and a certain range of environmental expenditure items, it is proposed to fill in such registers of synthetic and analytical accounting of environmental costs: "Statement of cost accounting for environmental activities of forestry"; "Summary statement of environmental cost accounting by sources of financing" [41].

\subsection{The Effectiveness of the Environmental Activities}

Environmental performance and effectiveness are determined from different perspectives, ranging from the assessment and analysis of income from environmental activities to the assessment of damage prevention. The complex and multidimensional nature of the relationship between the production and environmental activities of forest enterprises does not provide an opportunity to accurately assess the transition of ecological and economic systems to a higher level of operation.

The objectives of the environmental performance analysis are: assessing the implementation of the plan in accordance with the relevant indicators; assessing the factors that affect the results achieved; to determine, in accordance with the results achieved, the permissible pollution of environmental components and the average industry standards for the use of natural resources; assessment of the existing organizational and technical level of environmental activities and planned environmental activities according to the data obtained in the analysis of the results of activities to improve the use of natural resources; and the choice of environmental measures that will further improve environmental performance [44].

The improvement and significant growth of economic criteria of efficiency of production and financial activity does not necessarily lead to improvement of environmental performance indicators. A qualitative change in these indicators occurs when the level of utilization of production resources is sufficiently high [42]. It is possible to determine this despite the whole variety of its forms, by using the whole complex of analytical instruments. Here, it is important to find the optimal ratio in the middle of each of the applied methodological techniques, ensuring a differentiated approach to the phenomena and processes studied. In environmental management, this means the need for a quantitative perception of the conditions and scope of reconstruction and modernization of production, according to which the transition to a different level of environmental activity begins.

The analysis of environmental performance in the overall context of resource conservation does not solve the question of assessing the effectiveness of environmental measures themselves. Environmental protection has long been a relatively independent area, although without institutional foundations. Most of economic entities allocate financial and other resources to some extent for conservation [45]. The establishment and operation of environmental units raises the question of monitoring their implementation, taking into account the effectiveness assessment.

As a result of the study and synthesis of environmental performance indicators systems, we propose analysing the effectiveness of environmental activities of forestry enterprises in the following stages: economic, environmental and social (Table 2).

The testing of all the indicators in Table 2 is currently not possible for forestry enterprises, since in practice current and capital conservation costs are not allocated to a separate group, but are included in the total cost of production, which requires time-consuming sampling of primary documents, statistical calculations and expert estimates, and complicates the expediency of their implementation. In addition, a large part of the sources cited is purely internal and confidential information of forestry enterprises. In view of this, Table 2 proposes the introduction of a number of analytical accounts intended for the accumulation and movement of current and capital environmental expenditures in the accounting system. 
Table 2. Indicators for environmental performance in the forestry sector of Ukraine.

\begin{tabular}{|c|c|c|c|c|}
\hline Dimension & Indicator & Definition & $\begin{array}{l}\text { Desirable Trend of } \\
\text { the Indicator }\end{array}$ & $\begin{array}{c}\text { Sources of Information for } \\
\text { Calculation }\end{array}$ \\
\hline \multirow{3}{*}{$\begin{array}{l}\text { Economic } \\
\text { impact }\end{array}$} & $\begin{array}{l}\text { Overall economic } \\
\text { effectiveness of } \\
\text { environmental } \\
\text { expenditures }\end{array}$ & $\begin{array}{c}E_{g e n}=\frac{E E_{f g}}{C E E}, \\
\text { where } E_{g e n} \text { is the overall effectiveness of } \\
\text { environmental costs; } \\
E E_{f g} \text { is the ecological and economic impact of } \\
\text { environmental measures implemented (the total } \\
\text { increase in the forest resource value); } \\
C E E \text { is the cumulative environmental } \\
\text { expenditure that has contributed to this effect. }\end{array}$ & $\max$ & \multirow{3}{*}{$\begin{array}{l}\text { Data of analytical account } 237 \\
\text { "Environmental expenses", } 915 \\
\text { "Environmental expenses", } 719 \\
\text { "Operational income from } \\
\text { environmental activities", } 747 \\
\text { "Income from capital environmental } \\
\text { measures". Analytical accounting on } \\
\text { accounts 15 “Capital construction", } 98 \\
\text { "Tax on profit". }\end{array}$} \\
\hline & $\begin{array}{c}\text { Effectiveness of } \\
\text { capital environmental } \\
\text { expenditure }\end{array}$ & $\begin{array}{c}E_{k}=\frac{E E_{f g}-E_{o}}{C N E}, \\
\text { where } E_{k} \text { is effectiveness of capital } \\
\text { environmental costs; } \\
E_{o} \text { is operating expenses for maintenance of } \\
\text { environmental objects; } \\
C N E \text { is the capital expenses for nature } \\
\text { protection. }\end{array}$ & $\max$ & \\
\hline & $\begin{array}{l}\text { Net economic impact } \\
\text { of environmental } \\
\text { measures }\end{array}$ & $\begin{array}{c}N E E=E_{g e n}-E_{e} \\
\text { where } N E E \text { is the net economic effect; } \\
E_{e} \text { is the costs of relevant environmental } \\
\text { activities; } \\
E_{g e n} \text { - the economic effect of the implementation } \\
\text { of nature protection activities: } \\
E_{g e n}=E L+\Delta \mathrm{I} \\
E L \text { is prevented loss from pollution of forests; } \\
\Delta \mathrm{I} \text { is the growth of income from the activities of } \\
\text { the enterprise due to environmental } \\
\text { improvement. }\end{array}$ & $\max$ & \\
\hline $\begin{array}{l}\text { Environmental } \\
\text { impact }\end{array}$ & $\begin{array}{l}\text { Average reduction in } \\
\text { negative impact on } \\
\text { forest resources }\end{array}$ & $\begin{array}{c}E_{r e}=\frac{\Delta I_{r e}}{T E E}, \\
\text { where } E_{r e} \text { is the average reduction in the } \\
\text { negative impact on forest resources; } \\
\Delta I_{r e} \text { - reduction in negative impacts on forest } \\
\text { resources; } \\
T E E \text { is the total environmental expenditure that } \\
\text { has contributed to this effect. }\end{array}$ & $\max$ & $\begin{array}{l}\text { Management reporting data: } \\
\text { "Statement of cost accounting for } \\
\text { environmental activities of forestry", } \\
\text { "Summary of cost accounting for } \\
\text { environmental activities by sources of } \\
\text { financing", form 10-LH "Report on } \\
\text { the implementation of the production } \\
\text { plan for forestry". }\end{array}$ \\
\hline Social impact & $\begin{array}{l}\text { Profitability of } \\
\text { environmental } \\
\text { activities from the } \\
\text { social viewpoint }\end{array}$ & $\begin{array}{l}\qquad \mathrm{R}=\frac{\sum_{m=1}^{M} \Delta y_{m}+P w}{\sum_{i=1}^{n} Z i}, \\
\text { where } R \text {-profitability of environmental activities } \\
\text { from the point of view of society; } \Delta y_{m} \text { is } \\
\text { reduction in environmental fees and payments; } \\
P_{w} \text { is additional profit from the sales of waste to } \\
\text { third party enterprises or their own processing } \\
\text { and sale of products to buyers; } Z_{i} \text { is the costs of } \\
\text { implementation of } I \text { environmental action. }\end{array}$ & $\max$ & $\begin{array}{l}\text { Data of analytical accounting on } \\
\text { accounts } 36 \text { "Calculations with buyers } \\
\text { and customers", } 37 \text { "Calculations } \\
\text { with other debtors", } 915 \text { "Expenses on } \\
\text { environmental activity". } \\
\text { Tax and financial reporting data. }\end{array}$ \\
\hline
\end{tabular}

Note: enterprises need to keep records of such expenses as total environmental costs in order to calculate the absolute profitability of the environmental costs; environmental operating and capital costs in order to calculate their effectiveness in the implementation of environmental protection measures. Source: developed by the authors.

The objective of the analysis of environmental performance of forestry enterprises is to prepare analytical information necessary for making sound management decisions that would allow enterprises to achieve maximum cost-effectiveness of environmental activities with maximum consideration of requirements of the sustainable development goals in the area of forest resources.

Environmental performance indicators reproduce the environmental impact of the environmental project, which can be expressed in the ecological capacity of the territory, increasing biodiversity and increasing the assimilation potential of the territory [46]. Also, indicators of environmental efficiency can be included that characterize the dynamics of emission reductions and discharges. As a result, the environment becomes less polluted, and thus more resistant to negative anthropogenic influences due to human economic activity. 
The objectives and results of environmental activities are also linked to the cost-effectiveness of the environmental performance of the enterprise—environmental profitability $(R)$ [47]:

$$
R=\frac{\sum_{i=1}^{n} P_{i}}{\sum_{i=1}^{n} Z_{i}}
$$

where $P$ is the benefit of implementation of environmental action $i$; $Z$ is the cost of implementation of environmental protection measure $i$; and $n$ is the number of environmental measures.

From the point of view of the enterprise, the environmental damage is not accounted for in the case it is not properly internalized through, e.g., administrative actions of the government authorities, which then decrease the profitability of the enterprise. For this external effect, economic methods for reducing the pollution of the environment used by the enterprise include profit taxes or increases in the production costs through, e.g., value-added tax. Thus, the result of the environmental action is a reduction in the cost of production or a reduction in the payments from profit. The enterprise is also interested in obtaining additional profit through the sale of production waste. In addition, for the implementation of environmental activities, the enterprise can receive a preferential credit, which serves as an incentive for the implementation of environmental measures and increases their effectiveness, and receive funds of targeted financing (subsidies) from local or regional budgets, which affect the assessment of the effectiveness of environmental measures. Taking into account all the above factors, the profitability of an environmental strategy at the level of an individual enterprise is obtained as:

$$
R=\frac{\sum_{m=1}^{M} \Delta y_{m}+P_{w}+P_{c r}}{\sum_{i=1}^{n} Z_{i}-Z_{g r}},
$$

where $\Delta y_{m}$ is the reduction in environmental fees and payments; $m$ indicates the types of environmental fees and payments (fees, environmental tax, special use of forest resources); $M$ is the number of environmental payments; $P_{w}$ is the income from the sale of waste to third-party enterprises or their own processing and sale of products to buyers; $P_{c r}$ is the reduction in the payment for the received credit; $Z_{i}$ is the costs of implementation of environmental management measure $i$; and $Z_{g r}$ is the value of grants received by the enterprise. In addition to profitability, the payback period can also be used to assess the cost-effectiveness of environmental measures, which is calculated as a reverse ratio to profitability, that is, $1 / \mathrm{R}$.

The social effectiveness of environmental activities is primarily assessed by harm reduction caused by exploitation of the forest resources. A company is also interested in waste processing, coinciding with the interests of the enterprise. Thus, the profitability of environmental activities from the point of view of society, we suggest, is expressed by the formula:

$$
R=\frac{\sum_{m=1}^{M} \Delta y_{m}+P_{w}}{\sum_{i=1}^{n} Z_{i}} .
$$

The social effectiveness of environmental measures is determined by comparing the indicators that characterize the social result (effect of changes in social indicators before and after the introduction of environmental measures) to the costs necessary to achieve them.

We will build a simple optimization model for evaluating the effectiveness of environmental measures at the enterprise level on the basis of the net discounted income (NDI) indicator:

$$
N D I=\sum_{t=1}^{T} \frac{\Delta y_{t}+P_{w, t}+P_{c r, t}}{(1+r)^{t}}-\sum_{t=1}^{T} \frac{Z_{t}-Z_{g r, t}}{(1+r)^{t}}
$$

where $r$ is the discount rate for social and environmental measures, which is taken at the level of $50 \%$ of the inter-bank interest rate; and $t$ is the time period. Note that variables with sub-indexes $t$ denote the sums of respective indicators, i.e., $\Delta y_{t, m}=\sum_{m=1}^{M} \Delta y_{t, m}$ and $Z_{t}=\sum_{i=1}^{n} Z_{t, i}$. 
Due to limited data availability, we embark on an illustrative example to show the possibilities for applying the proposed indicators for valuation of the environmental measures (programmes). Suppose that the annual loss prevented (i.e., savings) due to implementation of the conservation measure is 50 thousand Euro per year. The capital costs ensuring eligibility for the participation are incurred in the first year ( 80 thousand Euro) and in the second year (60 thousand Euro). The observed inter-bank loan rate is $10 \%$. Ignoring the time effect, the simplest measure of the profitability of the participation in the programme is $50 /(80+60)=0.36=36 \%$. However, a more detailed analysis can be applied by following the logics outlined in Equation (4). As we equate the discount rate to 50\% of the inter-bank loan interest rate, the discount rate of $5 \%$ is used for calculation of the discount factor. The calculation of the NDI for the time horizon of eight years is presented in Table 3.

Table 3. Calculation of the net discounted income (NDI) for an environmental measure.

\begin{tabular}{|c|c|c|c|c|c|c|}
\hline Year & $\begin{array}{l}\text { Annual Reduction } \\
\text { in Damage to } \\
\text { Forest Resources, } \\
\text { Thousand Euro }\end{array}$ & $\begin{array}{c}\text { Annual Amount } \\
\text { of Capital } \\
\text { Conservation } \\
\text { Expenditures, } \\
\text { Thousand Euro }\end{array}$ & $\begin{array}{c}\text { Cash Flow, } \\
\text { Thousand } \\
\text { Euro }\end{array}$ & $\begin{array}{l}\text { Discount } \\
\text { Factor }\end{array}$ & $\begin{array}{l}\text { Discounted } \\
\text { Cash Flow, } \\
\text { thousand } \\
\text { Euro }\end{array}$ & $\begin{array}{c}\text { NDI, } \\
\text { Thousand } \\
\text { Euro }\end{array}$ \\
\hline 1 & - & 80 & -80 & 1 & -80.0 & -80.0 \\
\hline 2 & - & 60 & -60 & 0.95 & -57.0 & -137.0 \\
\hline 4 & 50 & - & 50 & 0.86 & 43.0 & -48.5 \\
\hline 5 & 50 & - & 50 & 0.82 & 41.0 & -7.5 \\
\hline 6 & 50 & - & 50 & 0.78 & 39.0 & 31.5 \\
\hline 7 & 50 & - & 50 & 0.74 & 37.0 & 68.5 \\
\hline 8 & 50 & - & 50 & 0.71 & 35.5 & 104.0 \\
\hline
\end{tabular}

Source: developed by the authors.

On the basis of these calculations, a schedule of changes in the NDI by years is established (Figure 5). Following the assumptions of the model, the lowest NDI is achieved if the environmental programme stops in Year 3, i.e., after consecutive investments are done and no positive impacts are obtained yet.

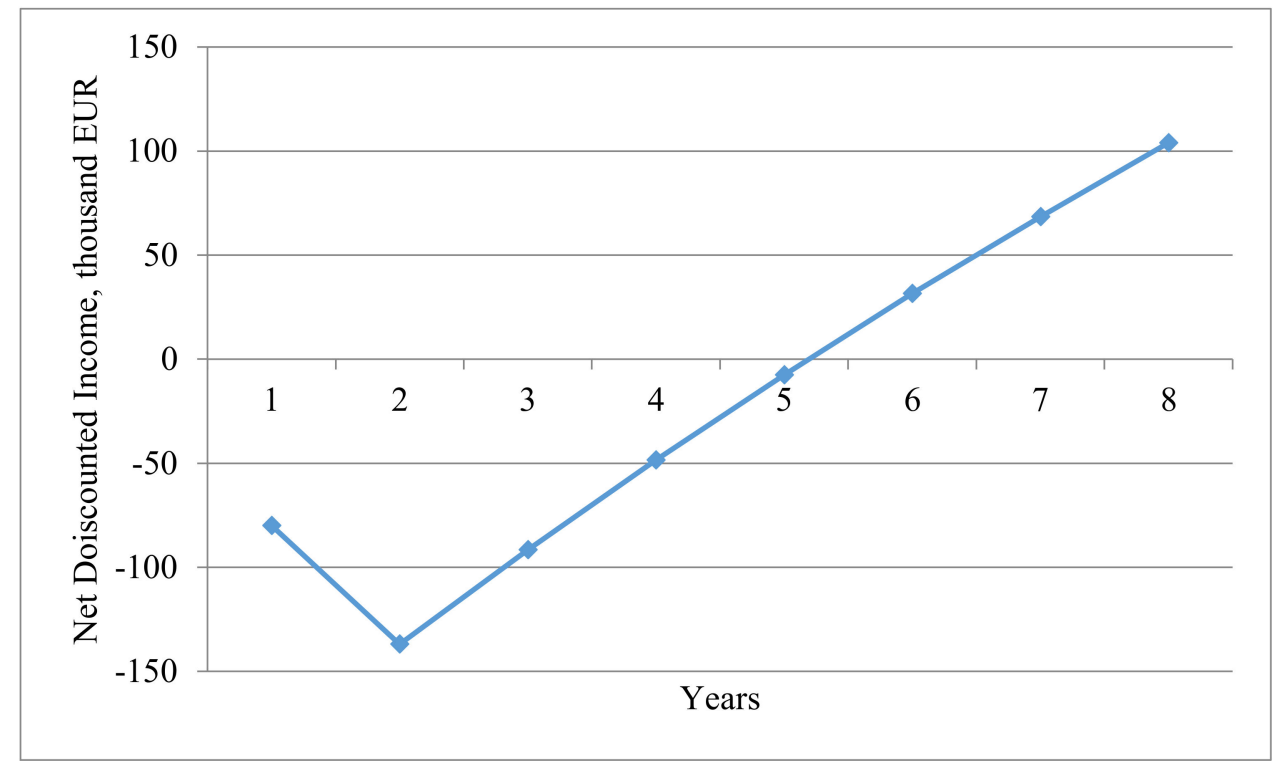

Figure 5. Schedule of net discounted income from the implementation of the environmental measure. Source: developed by the authors.

If, for a given period of time, $t_{0}$, the positive NDI is observed, i.e., NDI $>0$, the programme is economically justified. On the contrary, if $N D I<0$, then the environmental programme is not 
economically justified. The data in Table 3 and Figure 5 suggest that the NDI schedule crosses the time axis (i.e., changes sign from negative to positive) in between Years 5 and 6 . Thus, the payback period is over 5 years (and less than 6 years). The specific length of the payback period is obtained as

$$
T_{0}=\frac{t_{0}-\mathrm{NDI}\left(t_{0}\right)}{\mathrm{NDI}\left(t_{0}-1\right)-\mathrm{NDI}\left(t_{0}\right)}
$$

According to Equation (5), we get $T_{0}=\frac{5-(-7.5)}{31.5-(-7.5)}=5.2$ [years]. This implies that the payback period is 5.2 years. If the environmental programme ensures the flow of income beyond this time point, the forest enterprise can commit to such a programme.

\section{Discussion}

The method of evaluating the environmental performance in forestry which is proposed in the research is the result of scientific works in the sphere of accounting and analysis of environmental activities of forestry enterprises $[17,40]$. No analogues have been found in Ukraine and the world at this time.

The factors for achieving high environmental performance are: the close relationship of the environmental action plan to the following sections, such as production and sales (all of these changes in the volume and nomenclature of products produced should be harmonized with the capabilities of existing environmental facilities, and if they are insufficient, appropriate changes should be made to production plans or environmental action plans); technological and organizational development (the application of new technology and technologies should also take into account the need for environmental protection); standards and norms (because the necessity of environmental measures and the results of environmental activities depend to a large extent on the availability and observance of progressive norms of consumption of materials, fuel and other natural resources by the enterprise); successful implementation of planned environmental measures; high organizational and technical level of production in general and especially environmental activities; concentration of production and increase in capacities of technological units; condition and compliance with the rules of operation of technological and environmental equipment, as well as optimal technological regimes. This factor should be particularly important, as it allows for better environmental performance, not only at no additional cost, but also with a noticeable production effect.

In the context of economic imbalance at the local and regional levels and the influence of many factors on the results of forest operations, it is advisable to use mathematical modeling methods (in particular, simulation modeling) as a powerful tool to identify the weak and strong sides of the enterprise's activity, to determine the imbalances that hinder its development, and to simulate the results of environmental activities with a high degree of reliability.

However, in order to achieve reliable results, a database should be established that could be used in the modeling of performance. Simulation results can be used to develop a system of experiments of environmental activities processes for the design, analysis and evaluation of the functioning of the modeling object. It will also allow researchers to investigate and experiment with internal relations in the system. In addition, based on the knowledge gained in the design of the simulation model, it is possible to determine ways to improve the system that is modeled. By modifying input data, it is useful to identify which variables are most important and how they interact.

\section{Conclusions}

In order to establish a reliable accounting and analytical framework for assessing the effectiveness of environmental measures and implementation of the management objectives, the sectoral characteristics of forestry should be taken into account. These include the structure and volumes of production, the control system, the nature and purpose of production processes, the complexity and complexity of production, high labor intensity and material intensity. 
A decision-making system for assessing and analysing economic, environmental and social effects of environmental activities of forestry enterprises should be established, which will allow researchers to optimize the process of making management decisions on the effectiveness of environmental activities of forest farms.

The economic optimization model of profitability of environmental measures based on net discounted income indicator was constructed in this study. It allows one to determine the optimal level of involvement in the voluntary environmental programmes. Indicators of economic, ecological and social effectiveness of environmental costs, profitability of environmental activities and net discounted income form the environmental activities can act as a basis for adjusting the needs of financing from the state budget or extra budgetary funds of the environmental programmes.

In this paper, we carried out algebraic calculations to demonstrate the operation of the proposed measures. However, further research could embark on developing more complex models seeking to optimize the net discounted income over a certain time horizon with respect to different scenarios. This can be achieved by developing mathematical programming problems.

Author Contributions: Conceptualization, V.N. Formal analysis, I.Z.; Investigation, M.T. and V.T.; Writingoriginal draft, I.Z. and M.T.; Writing—review \& editing, T.B. and D.S. All authors have read and agreed to the published version of the manuscript.

Funding: This research received no external funding.

Conflicts of Interest: The authors declare no conflict of interest.

\section{References}

1. Food and Agriculture Organization of the United Nations. The State of the World's Forests: Ways to Achieve Sustainable Development, Taking into Account the Importance of Forests; Food and Agriculture Organization of the United Nations: Rome, Italy, 2018.

2. Sugiura, K.; Oki, Y. Reasons for Choosing Forest Stewardship Council (FSC) and Sustainable Green Ecosystem Council (SGEC) schemes and the effects of certification acquisition by forestry enterprises in Japan. Forests 2018, 9, 173. [CrossRef]

3. Bartniczak, B.; Raszkowski, A. Sustainable forest management in Poland. Manag. Environ. Qual. 2018, 29, 666-677. [CrossRef]

4. Environment of Ukraine to 2018. Statistical Collection 2019. Available online: http://www.ukrstat.gov.ua (accessed on 23 September 2019).

5. Sustainable Development Goals 2016-2030. Available online: http://www.un.org.ua/ua/tsili-rozvytkutysiacholittia/tsili-staloho-rozvytku (accessed on 7 April 2020).

6. Plans and Reports on the Work of the State Forest Resources Agency of Ukraine. Available online: http://dklg.kmu.gov.ua/forest/control/uk/publish/category?cat_id=34185 (accessed on 6 October 2019).

7. Lu, S.; Tang, X.; Guan, X.; Qin, F.; Liu, X.; Zhang, D. The assessment of forest ecological security and its determining indicators: A case study of the Yangtze River Economic Belt in China. J. Environ. Manag. 2020, 258, 110048. [CrossRef] [PubMed]

8. Schweier, J.; Magagnotti, N.; Labelle, E.R.; Athanassiadis, D. Sustainability impact assessment of forest operations: A review. Curr. For. Rep. 2019, 5, 101-113. [CrossRef]

9. Mäkelä, M. Trends in environmental performance reporting in the Finnish forest industry. J. Clean. Prod. 2017, 142, 1333-1346. [CrossRef]

10. Song, M.L.; Fisher, R.; Wang, J.L.; Cui, L.B. Environmental performance evaluation with big data: Theories and methods. Ann. Oper. Res. 2018, 270, 459-472. [CrossRef]

11. Czyżewski, B.; Matuszczak, A.; Miśkiewicz, R. Public goods versus the farm price-cost squeeze: shaping the sustainability of the EU's Common Agricultural Policy. Technol. Econ. Dev. Eco. 2019, 25, 82-102. [CrossRef]

12. Raszkowski, A.; Bartniczak, B. Towards Sustainable Regional Development: Economy, Society, Environment, Good Governance Based on the Example of Polish Regions. Transf. Bus. Econ. 2018, 17, 225-245.

13. Turturean, C.I.; Asandului, L.A.; Chirila, C.; Homocianu, D. Composite index of sustainable development of EU countries' economies (ISDE-EU). Transf. Bus. Econ. 2019, 18, 586-605. 
14. State Forestry Committee of Ukraine. Guidelines for Formation of the Cost of Goods (Works, Services) in Ukraine's Forestry. 2002. Available online: http://www.kadrlis.com.ua/normatuvna_baza.htm (accessed on 12 June 2019).

15. Cabinet of Ministers of Ukraine, List of Activities Belonging to Environmental Measures. 1996. Available online: http://search.ligazakon.ua/1_doc2.nsf/link1/KP961147.html (accessed on 25 September 2019).

16. Report on the Results of Implementation of the State Target Program "Forests of Ukraine" for 2010-2015. Available online: http://dklg.kmu.gov.ua (accessed on 2 October 2019).

17. United Nations. Environmental Management Accounting Procedures and Principles; Prepared For the Expert Working Group on "improving the role of government in the promotion of environmental management accounting"; United Nations Division for Sustainable Development: New York, NY, USA, 2001.

18. Zamula, I.V. Accounting of Environmental Activities in Ensuring Sustainable Development of the Economy: Monograph; ZhDTU: Zhitomir, Ukraine, 2010.

19. Popović, B.; Janković Šoja, S.; Paunović, T.; Maletić, R. Evaluation of sustainable development management in EU countries. Sustainability 2019, 11, 7140. [CrossRef]

20. United Nations; European Commission; International Monetary Fund; Organization for Economic Co-operation and Development; World Bank. Integrated Environmental and Economic Accounting; United Nations: New York, NY, USA; European Commission: Brussels, Belgium; International Monetary Fund: Washington, DC, USA; Organization for Economic Co-operation and Development: Paris, France; World Bank: Washington, DC, USA, 2003.

21. Zandi, G.; Lee, H. Factors affecting environmental management accounting and environmental performance: An empirical assessment. Int. J. Energy Econ. Policy 2019, 9, 342-348. [CrossRef]

22. Nigri, G.; Del Baldo, M. Sustainability reporting and performance measurement systems: How do smalland mediumsized benefit corporations manage integration? Sustainability 2018, 10, 4499. [CrossRef]

23. Zandi, G.; Khalid, N.; Zahurul Islam, D.M. Nexus of Knowledge Transfer, Green Innovation and Environmental Performance: Impact of Environmental Management Accounting. Int. J. Energy Econ. Policy 2019, 9, 387-393. [CrossRef]

24. Alaeddin, O.; Shawtari, F.; Salem, M.; Altounjy, R. The effect of management accounting systems in influencing environmental uncertainty, energy efficiency and environmental performance. Int. J. Energy Econ. Policy 2019, 9, 346-352. [CrossRef]

25. United Nations. System of Environmental Economic Accounting 2012; Central Framework; United Nations: New York, NY, USA, 2017.

26. Food and Agriculture Organization of the United Nations Statistical Division. System of EnvironmentalEconomic Accounting for Agriculture, Forestry and Fisheries (SEEA AFF); Food and Agriculture Organization of the United Nations Statistical Division: Rome, Italy, 2014.

27. IUFRO. Building insights of global economy and accounting toward sustainable forest management. In Proceedings of the IUFRO unit 4.05.00 International Symposium, Lviv, Ukraine, 17-19 May 2007; Zahvoyska, L., Jobstl, H., Kant, S., Maksyv, L., Eds.; UNFU Press: Lviv, Ukraine, 2009.

28. Krivačić, D.; Janković, S. Managing attitudes on Environmental Reporting: Evidence from Croatia. J. Environ. Account. Manag. 2017, 5, 327-341. [CrossRef]

29. Susanto, A.; Meiryani, M. The impact of environmental accounting information system alignment on firm performance and environmental performance: A case of small and medium enterprises of Indonesia. Int. J. Energy Econ. Policy 2019, 9, 229-236. [CrossRef]

30. Christine, D.; Yadiati, W.; Nur Afiah, N.; Fitrijanti, T. The relationship of environmental management accounting, environmental strategy and managerial commitment with environmental performance and economic performance. Int. J. Energy Econ. Policy 2019, 9, 458-464. [CrossRef]

31. Cavatassi, R. Validation Methods for Environmental Benefits in Forestry and Watt Investment Projects; The Food and Agriculture Organization of the United Nations: Rome, Italy, 2004.

32. IUFRO Research Group. Managing economy and accounting in an ever changing paradise of forest management. In International Symposium, 2nd ed.; Jobstl, H., Roder, C., Eds.; University of Applied Forest Sciences: Rottenburg, Germany, 2009.

33. Jobstl, H.A.; Hogg, J.N. State of forestry accounting in some European countries. Account. Manag. Econ. Environ. Friendly For. 2009, 15, 17-40. 
34. Toscani, P.; Walter Sekot, W. Forest accountancy data networks-A European approach of empirical research, its achievements, and potentials in regard to sustainable multiple use forestry. Forests 2018, 9, 220. [CrossRef]

35. Appiah, B.; Donghui, Z.; Majumder, S.; Monaheng, M. Effects of environmental strategy, uncertainty and top management commitment on the environmental performance: Role of environmental management accounting and environmental management control system. Int. J. Energy Econ. Policy 2020, 10, 360-370. [CrossRef]

36. Ning, Y.; Liu, Z.; Ning, Z.; Zhang, H. Measuring eco-efficiency of state-owned forestry enterprises in northeast China. Forests 2018, 9, 455. [CrossRef]

37. Head, M.; Bernier, P.; Levasseur, A.; Beauregard, R.; Margni, M. Forestry carbon budget models to improve biogenic carbon accounting in life cycle assessment. J. Clean. Prod. 2019, 213, 289-299. [CrossRef]

38. Yaremko, A.P. Analysis of efficiency of functioning and prospects of development of ecologically balanced forestry. Innovation 2017, 5, 103-108.

39. Lesyuk, G.M. Modern socio-economic approaches to forest management in Ukraine. Econ. Soc. 2017, 8, 470-476.

40. Sahoo, K.; Bergman, R.; Alanya-Rosenbaum, S.; Gu, H.; Liang, S.H. Life cycle assessment of forest-based products: A review. Sustainability 2019, 11, 4722. [CrossRef]

41. Tanasiieva, M.M. The Accounting and Analysis of Environmental Activities in Forestry: Author's Degree of Scientific Research; Accounting, Analysis and Audit (by Types of Economic Activity): Ternopil, Ukraine, 2016.

42. Berendt, F.; Fortin, M.; Suchomel, C.; Schweier, J. Productivity, costs, and selected environmental impacts of remote-controlled mini forestry crawlers. Forests 2018, 9, 591. [CrossRef]

43. Saienko, K. The Environmental Cost Accounting: Monographs; Finance and Statistics: Moscow, Russia, 2005.

44. Belousov, A.I. Course of Ecological and Economic Analysis: Teaching Method; Finance and Statistics: Moscow, Russia, 2010.

45. Demina, T.A. The Accounting and Analysis of Environmental Costs of Enterprises; Finance and Statistics: Moscow, Russia, 1990.

46. Balatsky, O.F. Economics and the Quality of the Natural Environment; Hydrometeoizdat: Moscow, Russia, 1984.

47. Krepsha, N.V. The Environmental Management and Environmental Economics: Study Method; Tomsk Political Engineering University: Tomsk, Russia, 2011.

(C) 2020 by the authors. Licensee MDPI, Basel, Switzerland. This article is an open access article distributed under the terms and conditions of the Creative Commons Attribution (CC BY) license (http://creativecommons.org/licenses/by/4.0/). 